\title{
Hepatic Galactose Metabolism Quantified in Humans Using 2-18F-Fluoro-2-Deoxy-D-Galactose PET/CT
}

\author{
Michael Sørensen ${ }^{1,2}$, Kasper Sandager Mikkelsen ${ }^{1}$, Kim Frisch ${ }^{1}$, Ludvik Bass ${ }^{3}$, Bo Martin Bibby ${ }^{4}$, \\ and Susanne Keiding ${ }^{1,2}$ \\ ${ }^{1}$ PET Centre, Aarhus University Hospital, Aarhus, Denmark; ${ }^{2}$ Department of Medicine V, Aarhus University Hospital, Aarhus, \\ Denmark; ${ }^{3}$ Department of Mathematics, University of Queensland, Brisbane, Australia; and ${ }^{4}$ Department of Biostatistics, Aarhus \\ University, Aarhus, Denmark
}

Accurate quantification of regional liver function is needed, and PET of specific hepatic metabolic pathways offers a unique method for this purpose. Here, we quantify hepatic galactose elimination in humans using PET and the galactose analog 2-18 F-fluoro-2-deoxy-D-galactose ( $\left.{ }^{18} \mathrm{~F}-\mathrm{FDGal}\right)$ as the PET tracer. Methods: Eight healthy human subjects underwent ${ }^{18} \mathrm{~F}-\mathrm{FDGal}$ PET/CT of the liver with and without a simultaneous infusion of galactose. Hepatic systemic clearance of ${ }^{18} \mathrm{~F}-\mathrm{FDGal}$ was determined from linear representation of the PET data. Hepatic galactose removal kinetics were determined using measurements of hepatic blood flow and arterial and liver vein galactose concentrations at increasing galactose infusions. The hepatic removal kinetics of ${ }^{18} \mathrm{~F}-\mathrm{FDG}$ al and galactose and the lumped constant (LC) were determined. Results: The mean hepatic systemic clearance of ${ }^{18} \mathrm{~F}-\mathrm{FDGal}$ was significantly higher in the absence than in the presence of galactose $(0.274 \pm 0.001$ vs. $0.019 \pm$ $0.001 \mathrm{~L}$ blood $/ \mathrm{min} / \mathrm{L}$ liver tissue; $P<0.01$ ), showing competitive substrate inhibition of galactokinase. The LC was $0.13 \pm 0.01$, and the ${ }^{18} \mathrm{~F}$-FDGal PET with galactose infusion provided an accurate measure of the local maximum removal rate of galactose $\left(\mathrm{V}_{\text {max }}\right)$ in liver tissue compared with the $\mathrm{V}_{\text {max }}$ estimated from arterio-liver venous $(A-V)$ differences $(1.41 \pm 0.24$ vs. $1.76 \pm 0.08$ $\mathrm{mmol} / \mathrm{min} / \mathrm{L}$ liver tissue; $P=0.60$ ). The first-order hepatic systemic clearance of ${ }^{18} \mathrm{~F}-\mathrm{FDG}$ al was enzyme-determined and can thus be used as an indirect estimate of galactokinase capacity without the need for galactose infusion or knowledge of the LC. Conclusion: ${ }^{18} \mathrm{~F}-\mathrm{FDG}$ al PET/CT provides an accurate in vivo measurement of human galactose metabolism, which enables the quantification of regional hepatic metabolic function.

Key Words: hepatic metabolic function; galactose metabolism; Michaelis-Menten kinetics; molecular imaging; nuclear hepatology

J Nucl Med 2011; 52:1566-1572

DOI: 10.2967/jnumed.111.092924

\footnotetext{
A n accurate method for preoperative quantification of regional hepatic function is important to accurately predict

Received May 9, 2011; revision accepted Jul. 14, 2011.

For correspondence or reprints contact: Michael Sørensen, PET Centre, Aarhus University Hospital, DK-8000 Aarhus, Denmark.

E-mail: michael@pet.auh.dk

Published online Aug. 29, 2011.

COPYRIGHT @ 2011 by the Society of Nuclear Medicine, Inc.
}

the postoperative remnant liver function after, for example, resection of liver tumors. Methods for estimating different hepatic metabolic functions by SPECT have been published $(1,2)$, but compared with PET, SPECT suffers from low spatial and temporal resolution.

We recently developed a PET method in pigs that enables the quantification of regional hepatic removal rates of galactose using the galactose analog $2-{ }^{18} \mathrm{~F}$-fluoro-2-deoxy-D-galactose ( $\left.{ }^{18} \mathrm{~F}-\mathrm{FDGal}\right)(3)$, with good reproducibility (4). Galactose is almost exclusively metabolized in the liver, and the elimination rate of galactose from blood depends on the hepatic amount of the enzyme galactokinase, which phosphorylates galactose (5). The maximum hepatic removal rate of galactose can be estimated for the whole liver by the galactose elimination capacity test (5), which provides prognostic information on the survival probability of patients with acute liver failure (6), patients with cirrhosis $(7,8)$, and patients undergoing hepatic resection (9). Therefore, we believe that the ${ }^{18} \mathrm{~F}$-FDGal PET/CT method is a promising tool for the quantification of regional hepatic galactose metabolism in humans and that the method is likely to have significant clinical potential.

In the present study, we quantified the hepatic ${ }^{18} \mathrm{~F}-\mathrm{FDGal}$ kinetics in the human liver by performing 2 dynamic ${ }^{18} \mathrm{~F}-$ FDGal PET/CT studies in 8 healthy subjects. One of the PET/CT studies was performed with a simultaneous intravenous infusion of galactose, and the other PET/CT study was performed without a galactose infusion. In pigs, galactokinase has significantly different affinities for galactose and ${ }^{18} \mathrm{~F}-\mathrm{FDGal}$, which rendered it necessary to apply a lumped constant (LC) of 0.14 to the measured ${ }^{18} \mathrm{~F}$-FDGal kinetics for conversion to parameters of galactose kinetics (3). Because a similar substrate specificity has been reported for human galactokinase in vitro $(10,11)$, we also determined the LC for ${ }^{18} \mathrm{~F}-\mathrm{FDGal}$ in the human liver in the present study. The overall aim of the study was to validate the ${ }^{18} \mathrm{~F}-\mathrm{FDG}$ al PET/CT method for the quantification of regional hepatic galactose metabolism in humans.

\section{MATERIALS AND METHODS}

\section{Human Subjects}

Eight healthy human subjects with no history of liver disease were included. The subjects had responded to an advertisement in 
a local newspaper, and they were instructed not to take any food or drugs for $8 \mathrm{~h}$ before the studies, but they were free to drink water. They were also instructed not to consume alcohol for at least $24 \mathrm{~h}$ before the study. The subjects' sex, age, and body weight are shown in Table 1. All patients had normal body mass index values (median, 24; range, 19-25) and normal galactose elimination capacity tests.

The study was approved by the Central Denmark Region Committees on Biomedical Research Ethics and conducted in accordance with the Helsinki II Declaration. Written informed consent was obtained from each subject. The mean radiation dose received by each subject was $7 \mathrm{mSv}$, and no complications associated with the procedures were observed.

\section{Study Design}

The subjects underwent 2 dynamic ${ }^{18} \mathrm{~F}-\mathrm{FDG}$ al PET/CT studies on separate days. One PET/CT study was performed with and the other PET/CT study was performed without a simultaneous intravenous infusion of galactose. The radioactive half-life of ${ }^{18} \mathrm{~F}$ (110 min) prevented more than one ${ }^{18}$ F-FDGal study in the same subject per day. Hepatic galactose elimination kinetics were determined by measuring the hepatic removal rates of galactose at 6 increasing levels of blood galactose. This part of the study was performed after the PET study without galactose infusion, and the hepatic blood flow was measured throughout this study day.

\section{Liver Vein Catheterization}

For the PET study without galactose infusion and the subsequent determination of hepatic galactose kinetics, a liver vein catheter (5-French catheter; Cook) was placed via an introducer catheter in the right femoral vein for liver blood sampling; the position of the catheter within the liver was verified before, during, and after the study by fluoroscopy using $5-15 \mathrm{~mL}$ of contrast agent (Omnipague, $240 \mathrm{mg} / \mathrm{mL}$; GE Healthcare).

\section{Hepatic Blood Flow}

Hepatic blood flow was determined by a constant intravenous infusion of indocyanine green (Hyson, Wescott and Dunning) (12). Sixteen pairs of blood samples were collected from a catheter placed in a radial artery (Artflon; Becton Dickinson) and the liver vein for the determination of plasma indocyanine green concentrations during the PET study without galactose infusion and the subsequent determination of galactose kinetics. No systematic variations during the day were observed, and the mean concentrations from the artery and liver vein were used to calculate a mean hepatic blood flow (F, L blood/min) for each subject according to the Fick principle and corrected for measured hematocrit (12).

\section{Hepatic ${ }^{18}$ F-FDGal Kinetics}

For both of the ${ }^{18} \mathrm{~F}-\mathrm{FDG}$ al PET/CT studies, the subjects were placed on their backs in a 40-slice Biograph TruePoint PET/CT camera (Siemens AG). A topogram of the abdomen was used for optimal positioning of the liver within the $21-\mathrm{cm}$ transaxial field of view of the PET camera. A low-dose CT scan (50 effective mAs with CAREDose4D; $120 \mathrm{kV}$; pitch, 0.8; slice thickness, $5 \mathrm{~mm}$ ) was obtained to define anatomic structures and attenuation correction of the PET data. A bolus of $100 \mathrm{MBq}$ of ${ }^{18} \mathrm{~F}-\mathrm{FDG}$ al (range, 96$104 \mathrm{MBq}$; radiochemical purity, $98 \% \pm 1 \%$ ) (13) in $10 \mathrm{~mL}$ of saline was administered at the beginning of a 60-min dynamic PET recording through an intravenous line (Venflon; Becton Dickinson) placed in a cubital vein. The PET data were recorded in list mode and reconstructed using iterative processing and a time-frame structure of $18 \times 5,15 \times 10,4 \times 30,4 \times 60$, and $10 \times 300 \mathrm{~s}$ (total, $60 \mathrm{~min}$ ) and corrected for radioactive decay back to the start of the recording, yielding 3-dimensional images of $128 \times 128 \times 47$ voxels and a central spatial resolution of $6.7 \mathrm{~mm}$ (full width at half maximum). The voxel size was $2.4 \times 2.4 \times 3.1 \mathrm{~mm}$. During both of the PET recordings, arterial blood samples $(0.5 \mathrm{~mL})$ were collected manually from the radial artery at $18 \times 5,6 \times 10,3 \times 20$, $3 \times 60,1 \times 120,1 \times 240,1 \times 360$, and $4 \times 600$ s to determine the ${ }^{18} \mathrm{~F}-\mathrm{FDG}$ al concentrations (well counter; Packard Instruments). The concentrations were corrected for radioactive decay back to the start of the PET recording (A*, Bq/L blood). During the PET study with no galactose infusion, liver vein blood samples $(0.5 \mathrm{~mL})$ were collected at the same time points as the arterial blood samples to determine the ${ }^{18} \mathrm{~F}$-FDGal concentrations in the liver vein blood $\left(\mathrm{V}^{*}, \mathrm{~Bq} / \mathrm{L}\right.$ blood).

During the PET study with simultaneous galactose infusion (infusion rate, $2.7-5.1 \mathrm{mmol} / \mathrm{min}$; priming dose, 30-45 mmol galactose), the infusion was started $60 \mathrm{~min}$ before the PET recording and continued throughout it. In addition to the arterial blood sam-

\section{TABLE 1}

Subject Characteristics and Hepatic Galactose Kinetics

\begin{tabular}{|c|c|c|c|c|c|c|c|c|c|}
\hline Subject no. & Sex & Age (y) & $\begin{array}{l}\text { Body } \\
\text { weight } \\
(\mathrm{kg})\end{array}$ & $\begin{array}{l}\text { Hepatic blood } \\
\text { flow } \\
\text { (L blood/min) }\end{array}$ & $\begin{array}{c}\mathrm{V}_{\max } \\
(\mathrm{mmol} / \mathrm{min})\end{array}$ & $\begin{array}{c}\mathrm{K}_{\mathrm{m}} \\
(\mathrm{mmol} / \mathrm{L} \text { blood })\end{array}$ & $\begin{array}{c}\mathrm{V}_{\max } / \mathrm{K}_{\mathrm{m}} \\
(\mathrm{L} \text { blood } / \mathrm{min})\end{array}$ & $\mathrm{V}_{\max } /\left(\mathrm{FK}_{\mathrm{m}}\right)$ & $\begin{array}{l}\text { Approximation } \\
\text { of } \mathrm{K}_{\text {syst }} \text { to } \mathrm{F}\end{array}$ \\
\hline 1 & Male & 65 & 86 & $1.17 \pm 0.06$ & $1.81 \pm 0.26$ & $0.59 \pm 0.15$ & $3.05 \pm 0.22$ & $2.60 \pm 0.19$ & $93 \%$ \\
\hline 2 & Male & 63 & 90 & $0.93 \pm 0.08$ & $5.34 \pm 0.68$ & $2.17 \pm 0.36$ & $2.46 \pm 0.07$ & $2.65 \pm 0.07$ & $93 \%$ \\
\hline 3 & Male & 55 & 92 & $1.76 \pm 0.14$ & $4.21 \pm 0.33$ & $1.00 \pm 0.15$ & $4.23 \pm 0.18$ & $2.41 \pm 0.10$ & $91 \%$ \\
\hline 4 & Female & 70 & 45 & $0.70 \pm 0.04$ & $2.33 \pm 0.41$ & $1.08 \pm 0.37$ & $2.16 \pm 0.29$ & $3.07 \pm 0.41$ & $95 \%$ \\
\hline 5 & Male & 58 & 73 & $1.34 \pm 0.12$ & $4.77 \pm 0.56$ & $1.52 \pm 0.28$ & $3.13 \pm 0.13$ & $2.34 \pm 0.09$ & $90 \%$ \\
\hline 6 & Female & 61 & 76 & $0.94 \pm 0.07$ & $1.95 \pm 0.35$ & $0.84 \pm 0.25$ & $2.31 \pm 0.21$ & $2.45 \pm 0.23$ & $91 \%$ \\
\hline 7 & Male & 55 & 92 & $0.90 \pm 0.05$ & $2.16 \pm 0.39$ & $0.87 \pm 0.33$ & $2.47 \pm 0.36$ & $2.76 \pm 0.40$ & $94 \%$ \\
\hline 8 & Male & 61 & 74 & $1.10 \pm 0.10$ & $2.26 \pm 0.36$ & $0.82 \pm 0.30$ & $2.77 \pm 0.42$ & $2.52 \pm 0.38$ & $92 \%$ \\
\hline Mean \pm SE & & & & $0.94 \pm 0.02$ & $2.66 \pm 0.13$ & $0.95 \pm 0.08$ & $2.74 \pm 0.05$ & $2.53 \pm 0.10$ & $92 \%$ \\
\hline
\end{tabular}

\footnotetext{
$\mathrm{V}_{\max } / \mathrm{K}_{\mathrm{m}}=$ intrinsic clearance of galactose; $\mathrm{F}=$ hepatic blood flow; $\mathrm{K}_{\text {syst }}=$ hepatic systemic clearance of galactose ( $\mathrm{L}$ blood/min); mean $\pm \mathrm{SE}=$ weighted mean $\pm \mathrm{SE}$ of weighted mean.

Individual values are given as estimate \pm SE of estimate.
} 
ples collected to determine the blood ${ }^{18} \mathrm{~F}$-FDGal concentrations, 4 arterial blood samples $(0.5 \mathrm{~mL})$ were collected during the PET recording at $0,20,40$, and $60 \mathrm{~min}$ for enzymatic determination of the galactose concentration (14). Good approximation to a constant galactose concentration was achieved in each subject, with no systematic deviation, and the individual mean arterial galactose concentration was used $\left(\mathrm{C}_{\mathrm{A}}, \mathrm{mmol} / \mathrm{L}\right.$ blood $)$.

A volume of interest (median size, $300 \mathrm{~mL}$ liver tissue; range, 175-600 mL liver tissue) was drawn manually within the liver tissue, $1.5-2 \mathrm{~cm}$ from the edge of the liver and avoiding the central part of the organ using the combined PET/CT images. The volume of interest was used to generate a radioactivity concentration time course (kBq/mL liver tissue vs. time). For each PET recording, an individual volume of interest was used.

The hepatic systemic clearance of ${ }^{18} \mathrm{~F}$-FDGal was determined according to the Gjedde-Patlak representation of data $(15,16)$, assuming irreversible metabolism (3). In this relationship, the influx constant of the tracer $\left(\mathrm{K}_{\mathrm{i}}, \mathrm{L}\right.$ blood $/ \mathrm{min} / \mathrm{L}$ tissue $)$ is given as the asymptote fitted to the linear part of the relationship between the radioactivity concentration time course in the tissue (PET) and the arterial blood samples (quasi-steady-state metabolism). In the present study, the slope was defined using the data measured at 6-20 min after ${ }^{18} \mathrm{~F}-\mathrm{FDG}$ al administration, during which time interval the graphical representation of data was linear. The hepatic systemic clearance of ${ }^{18} \mathrm{~F}$-FDGal from the PET study without galactose infusion was denoted as $\mathrm{K}_{- \text {gal }}^{*}$ (L blood/min/L liver tissue) and that from the PET study with galactose infusion was denoted as $\mathrm{K}_{+ \text {gal }}^{*}(\mathrm{~L}$ blood/min/L liver tissue $)$. Assuming there is no substantial prehepatic (i.e., splanchnic) ${ }^{18} \mathrm{~F}$-FDGal metabolism, the mixed portal-arterial liver blood input (dual-input) can be replaced by the single arterial input for calculations of the kinetic parameters of quasi-steady-state metabolism (3). We note that $\mathrm{K}_{- \text {gal }}^{*}$ and $\mathrm{K}_{+ \text {gal }}^{*}$ per definition are systemic clearances.

The intrinsic clearance of ${ }^{18} \mathrm{~F}-\mathrm{FDGal}\left(\mathrm{V}_{\max }^{*} / \mathrm{K}_{\mathrm{m}}^{*}, \mathrm{~L}\right.$ blood/min) was calculated using $\mathrm{F}, \mathrm{A}^{*}$, and $\mathrm{V}^{*}$ measured at quasi-steady-state metabolism during the PET recording without galactose infusion (6-20 min after tracer injection) as $(17,18)$ :

$$
\mathrm{V}_{\max }^{*} / \mathrm{K}_{\mathrm{m}}^{*}=-\mathrm{F} \ln \left(1-\mathrm{E}^{*}\right),
$$

where $\mathrm{E}^{*}=\left(\mathrm{A}^{*}-\mathrm{V}^{*}\right) / \mathrm{A}^{*}$ is the hepatic extraction fraction of ${ }^{18} \mathrm{~F}$ FDGal, corrected for a mean splanchnic transit time of 1 min (19) to account for nonsteady state as the tracer was administered as a bolus. $\mathrm{V}_{\max }^{*} / \mathrm{K}_{\mathrm{m}}^{*}$ was used to calculate the hepatic systemic clearance of ${ }^{18} \mathrm{~F}-\mathrm{FDG}$ al for the whole liver $\left(\mathrm{K}_{\text {syst }}^{*}, \mathrm{~L}\right.$ blood/min) as (17):

$$
\mathrm{K}_{\mathrm{syst}}^{*}=\mathrm{F}\left(1-\mathrm{e}^{-\frac{\mathrm{V}_{\mathrm{max}}^{*}}{\mathrm{~F} \mathrm{~K}_{\mathrm{m}}^{*}}}\right) \text {. }
$$

Eq. 2

The clearance regime of ${ }^{18} \mathrm{~F}-\mathrm{FDG}$ al was determined from the ratio between $\mathrm{V}_{\max }^{*} / \mathrm{K}_{\mathrm{m}}^{*}$ and $\mathrm{F}$; for $\mathrm{V}_{\max }^{*} / \mathrm{K}_{\mathrm{m}}^{*}>>\mathrm{F}, \mathrm{K}_{\text {syst }}^{*}$ approximates $\mathrm{F}$ and is classified as predominantly flow-dependent, and for $\mathrm{V}_{\text {max }}^{*} / \mathrm{K}_{\mathrm{m}}^{*}<<\mathrm{F}, \mathrm{K}_{\text {syst }}^{*}$ approximates $\mathrm{V}_{\text {max }}^{*} / \mathrm{K}_{\mathrm{m}}^{*}$ and is classified as predominantly enzyme-determined (17). The approximations of $\mathrm{K}_{\text {syst }}^{*}$ to $\mathrm{F}$ and $\mathrm{V}_{\text {max }}^{*} / \mathrm{K}_{\mathrm{m}}^{*}$ were assessed quantitatively by the ratios $\mathrm{K}_{\text {syst }}^{*}$ to $\mathrm{F}$ and $\mathrm{K}_{\text {syst }}^{*}$ to $\mathrm{V}_{\max }^{*} / \mathrm{K}_{\mathrm{m}}^{*}$, respectively.

\section{Hepatic Galactose Kinetics}

Galactose (Aarhus University Hospital Pharmacy) was infused at 6 increasing doses $(0.7-2.9 \mathrm{mmol} / \mathrm{min})$. Each measurement period was preceded by a 15 - to 35 -min equilibration period (20); a priming dose of galactose $(10-20 \mathrm{mmol})$ was given before the last 3 periods. During each measurement period, 4 pairs of blood samples were collected from the radial artery and the liver vein for determination of blood galactose concentrations (14). Good approximation to constant galactose concentrations was achieved in each measurement period, and the mean galactose concentrations in the artery $(\mathrm{A}, \mathrm{mmol} / \mathrm{L}$ blood) and liver vein ( $\mathrm{V}, \mathrm{mmol} / \mathrm{L}$ blood) were used.

For each subject, the hepatic $\mathrm{V}_{\max }(\mathrm{mmol} / \mathrm{min})$ and the Michaelis constant $\mathrm{K}_{\mathrm{m}}$ (mmol/L blood) for galactose were estimated according to the sinusoidal perfusion model of in vivo enzymatic elimination (21) by the nonlinear regression of the Michaelis-Menten relationship to the 6 sets of $\mathrm{v}$ and $\hat{\mathrm{C}}$ :

$$
\mathrm{v}=\mathrm{V}_{\max } \frac{\hat{\mathrm{C}}}{\hat{\mathrm{C}}+\mathrm{K}_{\mathrm{m}}} .
$$

where $\mathrm{v}$ is the hepatic removal rate of galactose calculated as $\mathrm{F}(\mathrm{A}-\mathrm{V})(\mathrm{mmol} / \mathrm{min})$ and $\hat{\mathrm{C}}(\mathrm{mmol} / \mathrm{L}$ blood $)$ is the mean logarithmic sinusoidal galactose concentration calculated as $(\mathrm{A}-\mathrm{V}) / \mathrm{ln}$ $(\mathrm{A} / \mathrm{V})$. The use of $\hat{\mathrm{C}}$ accounts for the decreasing blood galactose concentration along the sinusoid in vivo $(21,22)$.

The intrinsic clearance of galactose $\left(\mathrm{V}_{\max } / \mathrm{K}_{\mathrm{m}}, \mathrm{L}\right.$ blood $\left./ \mathrm{min}\right)$ was calculated, and the hepatic systemic clearance of galactose $\left(\mathrm{K}_{\text {syst }}, \mathrm{L}\right.$ blood/min) was calculated using Equation 2 with $\mathrm{V}_{\max } /$ $\mathrm{K}_{\mathrm{m}}$ instead of $\mathrm{V}_{\max }^{*} / \mathrm{K}_{\mathrm{m}}^{*}$. The clearance regime of galactose was determined and the ratios $\mathrm{K}_{\text {syst }}$ to $\mathrm{V}_{\text {max }} / \mathrm{K}_{\mathrm{m}}$ and $\mathrm{K}_{\text {syst }}$ to $\mathrm{F}$ were calculated.

\section{LC and Hepatic $V_{\max }$ of Galactose Measured by Dynamic ${ }^{18} \mathrm{~F}-\mathrm{FDG}$ al PET}

The LC for ${ }^{18} \mathrm{~F}$-FDGal was calculated as (3):

$$
\mathrm{LC}=\frac{\mathrm{V}_{\max }^{*} / \mathrm{K}_{\mathrm{m}}^{*}}{\mathrm{~V}_{\max } / \mathrm{K}_{\mathrm{m}}}
$$

that is, the ratio between the intrinsic clearance of ${ }^{18} \mathrm{~F}-\mathrm{FDGal}$, which was calculated from the concentration measurements in blood samples from the artery and liver vein during the ${ }^{18} \mathrm{~F}-\mathrm{FDGa}$ PET recording without simultaneous galactose (Eq. 1), and the intrinsic clearance of galactose, which was calculated from blood concentration measurements and Michaelis-Menten kinetics.

From the ${ }^{18} \mathrm{~F}$-FDGal PET recording with simultaneous galactose infusion, the hepatic $\mathrm{V}_{\max }$ of galactose per volume liver tissue $\left(\mathrm{V}_{\max }^{\mathrm{PET}}, \mathrm{mmol} / \mathrm{min} / \mathrm{L}\right.$ liver tissue) can be calculated as:

$$
\mathrm{V}_{\max }^{\mathrm{PET}}=\frac{\mathrm{K}_{+\mathrm{gal}}^{*} \mathrm{C}_{\mathrm{A}}}{\mathrm{LC}}\left(\frac{\mathrm{K}_{\mathrm{m}}+\hat{\mathrm{C}}}{\hat{\mathrm{C}}}\right),
$$

where $\mathrm{K}_{+\mathrm{gal}}^{*}$ is the hepatic systemic clearance of ${ }^{18} \mathrm{~F}-\mathrm{FDGal}(\mathrm{L}$ blood $/ \mathrm{min} / \mathrm{L}$ liver tissue), and $\mathrm{C}_{\mathrm{A}}$ is the mean arterial blood galactose concentration ( $\mathrm{mmol} / \mathrm{L}$ blood) during the PET recording. The ratio $\left(\mathrm{K}_{\mathrm{m}}+\hat{\mathrm{C}}\right) / \hat{\mathrm{C}}$ corrects for the individual approximation to near-saturation of the hepatic galactose elimination. As the present study was performed at near-saturated kinetics, $\hat{C}$ was replaced by $\mathrm{C}_{\mathrm{A}}$ in the calculations.

\section{Statistics}

The hepatic systemic clearance of ${ }^{18} \mathrm{~F}-\mathrm{FDG}$ al was calculated from linear regression of the PET data using maximum likelihood estimation. The estimation of hepatic galactose $V_{\max }$ and $K_{m}$ values included SEs of the estimates of $\mathrm{v}$ and $\hat{\mathrm{C}}$ in the nonlinear regression of the implicit relationship between the variables given 
by Equation 3, and the maximum likelihood estimation was used $(22,23)$. Individual data are presented as estimate \pm SE of the estimate. The weighted mean values of the individual estimates were calculated using the inverse estimated squared SEs as the weight.

\section{RESULTS}

The mean hepatic blood flow was $0.94 \mathrm{~L}$ blood $/ \mathrm{min}$ (range, 0.70-1.76 L blood/min) (Table 1), which is comparable to previously published observations using indocyanine green $(12,24)$ and transit-time ultrasound flow-meter measurements (25).

\section{Hepatic ${ }^{18}$ F-FDGal Kinetics}

The PET/CT images showed avid accumulation of ${ }^{18} \mathrm{~F}$ FDGal in the liver tissue compared with other tissues within the PET camera's field of view (Fig. 1). There was no sign of significant splanchnic ${ }^{18}$ F-FDGal accumulation, validating the use of the single arterial input instead of the dual-input for calculating the hepatic systemic clearance of ${ }^{18} \mathrm{~F}$-FDGal. The radioactivity concentration time course in the liver tissue showed that the infusion of galactose strongly inhibited hepatic tracer accumulation (Fig. 2). In agreement with this result, the mean hepatic systemic clearance decreased dramatically from $\mathrm{K}_{- \text {gal }}^{*}=0.274 \mathrm{~L}$ blood/ $\mathrm{min} / \mathrm{L}$ liver tissue to $\mathrm{K}_{+ \text {gal }}^{*}=0.019 \mathrm{~L}$ blood $/ \mathrm{min} / \mathrm{L}$ liver tissue $(P<0.01$, paired $t$ test) (Tables 2 and 3$)$. These results show that galactose and ${ }^{18}$ F-FDGal exhibit competitive inhibition for galactokinase and verify that ${ }^{18} \mathrm{~F}-\mathrm{FDG}$ can be used as a PET tracer of hepatic galactose metabolism in humans.

The mean $\mathrm{V}_{\max }^{*} /\left(\mathrm{FK}_{\mathrm{m}}^{*}\right)$ was 0.33 , and $\mathrm{K}_{\text {syst }}^{*}$ (mean, $0.32 \mathrm{~L}$ blood/min; range, $0.21-0.44 \mathrm{~L}$ blood/min) was accordingly predominantly enzyme-determined. The mean approximation of $\mathrm{K}_{\text {syst }}^{*}$ to $\mathrm{V}_{\text {max }}^{*} / \mathrm{K}_{\mathrm{m}}^{*}$ was $85 \%$ (Table 2 ).

\section{Hepatic Galactose Kinetics}

Table 1 summarizes the parameters of the hepatic galactose kinetics. The mean hepatic $\mathrm{V}_{\max }$ was $2.7 \mathrm{mmol} / \mathrm{min}$, and the mean Michaelis constant $\mathrm{K}_{\mathrm{m}}$ was $0.95 \mathrm{mmol} / \mathrm{L}$ blood, comparable to the mean in vitro $\mathrm{K}_{\mathrm{m}}$ of $0.97 \mathrm{mmol} / \mathrm{L}$ for human liver galactokinase $(10,11)$. The estimates of $\mathrm{V}_{\max }$ and $\mathrm{K}_{\mathrm{m}}$ were highly correlated within each individual (mean correlation, 93\%; range, 81\%-99\%), and the individual $\mathrm{V}_{\max } /$ $\mathrm{K}_{\mathrm{m}}$ ratios were accordingly estimated with high accuracy (22).

The mean $\mathrm{V}_{\max } /\left(\mathrm{FK}_{\mathrm{m}}\right)$ for galactose of 2.5 is comparable to the previously reported finding of 2.6 in healthy humans (24), and $\mathrm{K}_{\text {syst }}$ (mean 1.02 L blood/min; range, 0.67-1.21) was predominantly flow-determined. The mean approximation of $\mathrm{K}_{\text {syst }}$ to $\mathrm{F}$ was $92 \%$ (Table 1), which is also comparable to previously reported values $(24,26)$.

Correcting the $\mathrm{V}_{\max }$ of galactose for an assumed liver size of $2 \%$ of the body weight (27) and a liver tissue density of $1.07 \mathrm{~g} / \mathrm{mL}$ liver tissue yielded a mean $\mathrm{V}_{\max }$ of $1.76 \pm$ $0.08 \mathrm{mmol} / \mathrm{min} / \mathrm{L}$ liver tissue.

\section{LC and Hepatic $V_{\max }$ of Galactose Measured by ${ }^{18}$ F-FDGal PET}

Table 3 summarizes the galactose kinetics calculated from the ${ }^{18} \mathrm{~F}$-FDGal PET/CT data. The LC for ${ }^{18} \mathrm{~F}$-FDGal was $0.13 \pm 0.01$, which was significantly different from unity $(P<0.01)$. The mean hepatic $\mathrm{V}_{\max }$ of galactose $\left(\mathrm{V}_{\max }^{\mathrm{PET}}\right)$ was $1.41 \pm 0.24 \mathrm{mmol} / \mathrm{min} / \mathrm{L}$ liver tissue.

\section{DISCUSSION}

The aim of the present study was to quantify the regional galactose metabolism in the human liver in vivo using ${ }^{18} \mathrm{~F}$ FDGal PET/CT and to validate the measurements against direct, invasive measurements of hepatic galactose kinetics. Hepatic accumulation of the galactose analog ${ }^{18} \mathrm{~F}$-FDGal was strongly inhibited by the presence of galactose in the blood, verifying that ${ }^{18} \mathrm{~F}$-FDGal is metabolized by the same metabolic pathway as galactose in human liver in vivo. The maximum removal rate of galactose in the liver tissue calculated from ${ }^{18} \mathrm{~F}$-FDGal PET $\left(\mathrm{V}_{\max }^{\mathrm{PET}}\right)$ was $1.41 \pm 0.24$

TABLE 2

Hepatic ${ }^{18} \mathrm{~F}-\mathrm{FDG}$ al Kinetics in Absence of Galactose

\begin{tabular}{|c|c|c|c|c|}
\hline Subject no. & $\mathrm{V}_{\max }^{*} / \mathrm{K}_{\mathrm{m}}^{*}(\mathrm{~L}$ blood$/ \mathrm{min})$ & $\mathrm{V}_{\max }^{*} /\left(\mathrm{FK}_{\mathrm{m}}^{*}\right)$ & $\begin{array}{c}\text { Approximation } \\
\text { of } \mathrm{K}_{\mathrm{syst}}^{*} \text { to } \mathrm{V}_{\max }^{*} / \mathrm{K}_{\mathrm{m}}^{*}\end{array}$ & $\mathrm{~K}_{- \text {gal }}^{*}(\mathrm{~L}$ blood$/ \mathrm{min} / \mathrm{L}$ liver tissue $)$ \\
\hline 1 & $0.41 \pm 0.07$ & $0.35 \pm 0.06$ & $85 \%$ & $0.265 \pm 0.003$ \\
\hline 2 & $0.33 \pm 0.03$ & $0.36 \pm 0.04$ & $84 \%$ & $0.213 \pm 0.006$ \\
\hline 3 & $0.50 \pm 0.09$ & $0.29 \pm 0.06$ & $87 \%$ & $0.279 \pm 0.004$ \\
\hline 4 & ND & ND & ND & $0.229 \pm 0.008$ \\
\hline 5 & $0.52 \pm 0.09$ & $0.39 \pm 0.07$ & $83 \%$ & $0.342 \pm 0.004$ \\
\hline 6 & $0.33 \pm 0.04$ & $0.35 \pm 0.05$ & $84 \%$ & $0.253 \pm 0.004$ \\
\hline 7 & $0.24 \pm 0.06$ & $0.27 \pm 0.06$ & $88 \%$ & $0.273 \pm 0.002$ \\
\hline 8 & $0.32 \pm 0.06$ & $0.29 \pm 0.06$ & $87 \%$ & $0.295 \pm 0.008$ \\
\hline Mean \pm SE & $0.38 \pm 0.02$ & $0.33 \pm 0.02$ & $85 \%$ & $0.274 \pm 0.001$ \\
\hline
\end{tabular}

$\mathrm{V}_{\max }^{*} / \mathrm{K}_{\mathrm{m}}^{*}=$ intrinsic clearance of ${ }^{18} \mathrm{~F}-\mathrm{FDGal} ; \mathrm{F}=$ hepatic blood flow (L blood/min; Table 1$)$; $\mathrm{K}_{\text {syst }}^{*}=$ hepatic systemic clearance of ${ }^{18} \mathrm{~F}-\mathrm{FDGal} ; \mathrm{K}_{- \text {gal }}^{*}=$ hepatic systemic clearance of ${ }^{18} \mathrm{~F}-\mathrm{FDGal}$ calculated from PET study without galactose infusion; ND = not determined (in subject 4 , no liver vein blood samples were obtained during PET study); mean \pm SE = weighted mean \pm SE of the weighted mean. Individual values are given as estimate \pm SE of estimate. 
TABLE 3

Hepatic $V_{\text {max }}$ of Galactose Calculated from ${ }^{18} \mathrm{~F}-\mathrm{FDG}$ al PET/CT

\begin{tabular}{|c|c|c|c|c|}
\hline Subject no. & LC & $\mathrm{C}_{\mathrm{A}}(\mathrm{mmol} / \mathrm{L}$ blood $)$ & $\mathrm{K}_{+ \text {gal }}^{*}(\mathrm{~L}$ blood/min/L liver tissue $)$ & $\mathrm{V}_{\max }^{\mathrm{PET}}(\mathrm{mmol} / \mathrm{min} / \mathrm{L}$ liver tissue $)$ \\
\hline 1 & $0.13 \pm 0.02$ & $10.1 \pm 2.1$ & $0.014 \pm 0.002$ & $1.10 \pm 0.48$ \\
\hline 2 & $0.14 \pm 0.01$ & $6.5 \pm 1.3$ & $0.029 \pm 0.002$ & $1.85 \pm 0.60$ \\
\hline 3 & $0.12 \pm 0.02$ & $11.7 \pm 1.6$ & $0.011 \pm 0.002$ & $1.16 \pm 0.40$ \\
\hline 4 & ND & $7.1 \pm 0.5$ & $0.019 \pm 0.002$ & ND \\
\hline 5 & $0.17 \pm 0.03$ & ND & ND & ND \\
\hline 6 & $0.14 \pm 0.02$ & $10.1 \pm 0.6$ & $0.020 \pm 0.002$ & $1.51 \pm 0.53$ \\
\hline 7 & $0.10 \pm 0.03$ & $7.2 \pm 0.6$ & $0.025 \pm 0.006$ & $2.02 \pm 1.10$ \\
\hline 8 & $0.11 \pm 0.03$ & $9.2 \pm 0.7$ & $0.024 \pm 0.001$ & $2.11 \pm 0.96$ \\
\hline Mean $\pm S E$ & $0.13 \pm 0.01$ & $8.3 \pm 0.3$ & $0.019 \pm 0.001$ & $1.41 \pm 0.24$ \\
\hline
\end{tabular}

$\mathrm{LC}=$ lumped constant for ${ }^{18} \mathrm{~F}-\mathrm{FDGal} ; \mathrm{C}_{\mathrm{A}}=$ mean arterial blood concentration of galactose during the ${ }^{18} \mathrm{~F}-\mathrm{FDGal} \mathrm{PET}$ study with galactose infusion; $\mathrm{K}_{+ \text {gal }}^{*}=$ systemic hepatic clearance of ${ }^{18} \mathrm{~F}-\mathrm{FDG}$ al calculated from the PET study with galactose infusion; $\mathrm{V}_{\max }^{\mathrm{PET}}=$ maximum hepatic removal rate of galactose calculated from ${ }^{18} \mathrm{~F}-\mathrm{FDGal}$ PET data with galactose infusion (Eq. 5); ND = not determined (in subject 4, no liver vein blood samples were obtained during PET study; in subject 5, the PET study with galactose infusion was not performed; mean $\pm \mathrm{SE}$, weighted mean $\pm \mathrm{SE}$ of weighted mean.

Individual values are given as estimate \pm SE of estimate.

$\mathrm{mmol} / \mathrm{min} / \mathrm{L}$ liver tissue, and this result was not significantly different from the value of $1.76 \pm 0.08 \mathrm{mmol} / \mathrm{min} / \mathrm{L}$ liver tissue from invasive measurements that were corrected for liver size $(P=0.60$, paired $t$ test $)$. The ${ }^{18} \mathrm{~F}-\mathrm{FDG}$ al PET method thus provides an accurate measure of the $\mathrm{V}_{\max }$ of galactose in liver tissue by external detection. Because the hepatic galactose elimination capacity for the whole liver is predictive of the outcome after liver resection (9), the present method, which enables the estimation of regional hepatic metabolic function, is a promising candidate for preoperative prediction of the remnant liver function after, for example, liver resection for liver tumors.

Our LC of 0.13 was significantly different from unity, a result of the high substrate specificity of human galactokinase $(10,11)$. Biochemically, the $\mathrm{LC}$ is a result of the molecular difference between ${ }^{18} \mathrm{~F}-\mathrm{FDG}$ al and galactose, where the hydroxyl group at $\mathrm{C}-2$ in galactose is replaced by ${ }^{18} \mathrm{~F}$ in ${ }^{18} \mathrm{~F}$-FDGal (Fig. 3). When docked at the active site of galactokinase, the hydroxyl group at $\mathrm{C}-2$ in galactose assists in stabilizing the enzyme-substrate complex through

FIGURE 1. Transaxial (A) and coronal (B) ${ }^{18} \mathrm{~F}-\mathrm{FDGal}$ $\mathrm{PET} / \mathrm{CT}$ images of mean tissue radioactivity concentration ( $\mathrm{kBq} / \mathrm{mL}$ liver tissue) from PET study without galactose infusion (subject 6). The position of the liver vein catheter inserted via the right femoral vein is seen. Note that the tracer accumulates specifically in liver tissue. hydrogen bonding to a proximal carboxylate group of an aspartate residue of the enzyme (28). In ${ }^{18} \mathrm{~F}-\mathrm{FDG}$ al, the fluorine atom at $\mathrm{C}-2$ is unable to stabilize the complex to the same extent, and hence, the bonding of the tracer to galactokinase becomes less favorable. In agreement with neither glucokinase nor hexokinase being particularly substrate-specific (29), the in vivo LC for the commonly applied PET tracer of glucose metabolism ${ }^{18} \mathrm{~F}-\mathrm{FDG}$ was found to be not significantly different from unity in the pig liver (30).

In the present study, we determined the individual $\mathrm{K}_{\mathrm{m}}$ for the hepatic galactose metabolism, enabling us to calculate $\mathrm{V}_{\max }^{\mathrm{PET}}$ (Eq. 5). If the mean $\mathrm{K}_{\mathrm{m}}$ of 0.95 and the mean LC of 0.13 are considered as population means and the ${ }^{18} \mathrm{~F}-\mathrm{FDGal}$ $\mathrm{PET} / \mathrm{CT}$ study is performed with a galactose infusion ensuring a steady-state $\mathrm{C}_{\mathrm{A}}$ above $8 \mathrm{mmol} / \mathrm{L}$ blood (i.e., $\mathrm{C}_{\mathrm{A}}>8$ times $\mathrm{K}_{\mathrm{m}}$ ), then the correction for approximation to $\mathrm{V}_{\max }$ in Equation 5 can be neglected because $\mathrm{K}_{+\mathrm{gal}}^{*} \mathrm{C}_{\mathrm{A}} / \mathrm{LC}$ in this case approximates $\mathrm{V}_{\max }^{\mathrm{PET}}$ by more than $85 \%$, which is an acceptable approximation.

An interesting consequence of the different affinities of ${ }^{18} \mathrm{~F}-\mathrm{FDG} a \mathrm{l}$ and galactose for galactokinase resulted in the $\mathrm{K}_{\text {syst }}^{*}$ being enzyme-determined (on average, it approximated $\mathrm{V}_{\max }^{*} / \mathrm{K}_{\mathrm{m}}^{*}$ by $85 \%$ ), whereas $\mathrm{K}_{\mathrm{syst}}$ for galactose was predominantly flow-determined. Assuming that the Michaelis constant for a substrate is independent of the maximum removal rate, which is a reasonable assumption, then $\mathrm{K}_{- \text {gal }}^{*}$ provides an indirect measure of the regional $\mathrm{V}_{\max }^{*}$ without the need for a constant galactose infusion or knowledge of the individual LC. This is a key finding because the LC may change in parenchymal liver disease and it simplifies the setup for ${ }^{18} \mathrm{~F}-\mathrm{FDG}$ al PET/CT studies of the regional hepatic metabolic function.

Intrahepatic variation in parenchymal damage is well known in patients with liver diseases $(31,32)$, but corresponding changes in hepatic metabolic function have not yet been 


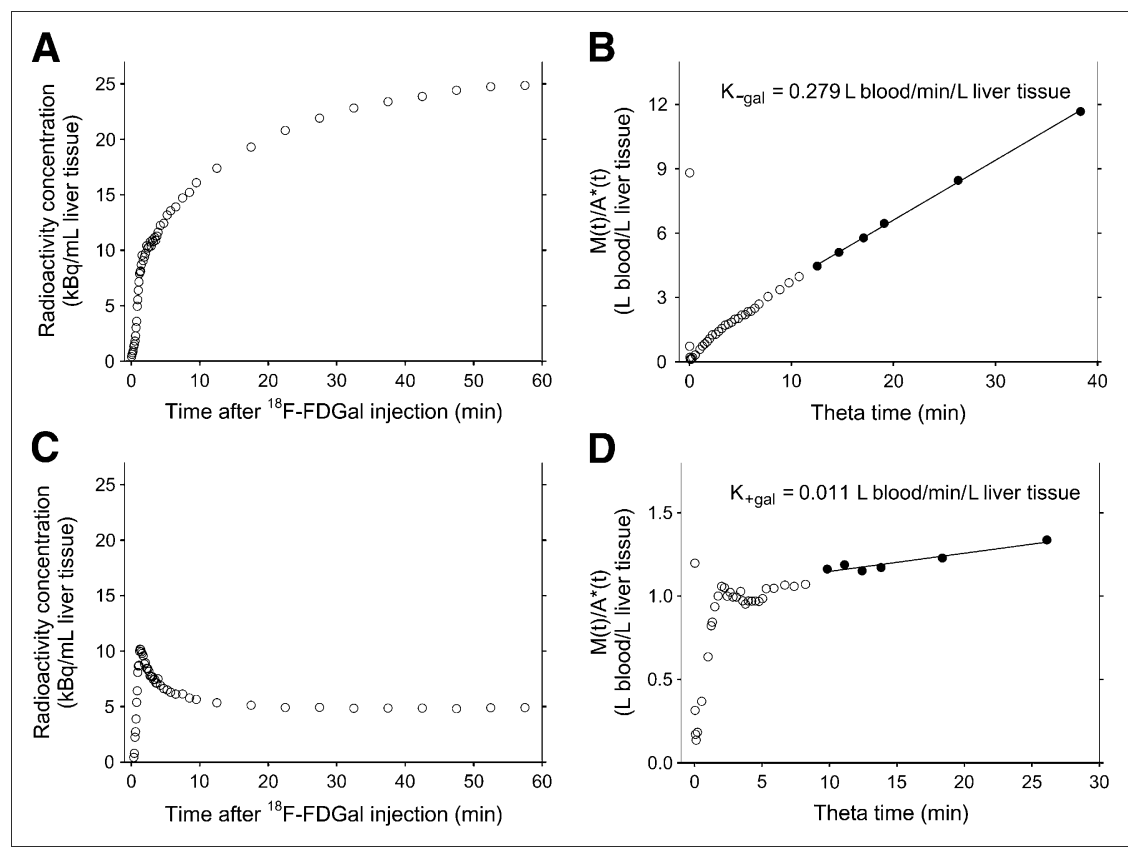

FIGURE 2. In vivo quantification of human hepatic ${ }^{18} \mathrm{~F}-\mathrm{FDG}$ al kinetics from dynamic PET data. Time course of radioactivity concentration in liver tissue during PET study without galactose infusion (A) with corresponding graphical representation of ${ }^{18} \mathrm{~F}-\mathrm{FDGal}$ data (B) according to Gjedde-Patlak $(15,16) . M(t)$ and $A^{*}(t)$ are radioactivity concentration time courses in liver tissue and arterial blood, respectively, and $\theta$ is virtual time calculated as integral of $A^{*}$ from time zero to time $t$ divided by $A^{*}(t)(15,16)$. In this analysis, hepatic systemic clearance of ${ }^{18} \mathrm{~F}-\mathrm{FDGal}$ (in absence of galactose; $\mathrm{K}_{- \text {gal }}^{*}$, $\mathrm{L}$ blood/min/L liver tissue) is given as the slope of the asymptote fitted to the linear part of plot (quasi-steady-state metabolism; 6-20 $\mathrm{min}$ after ${ }^{18} \mathrm{~F}-\mathrm{FDGal}$ administration). Corresponding data from PET study with simultaneous galactose infusion, including estimation of hepatic systemic clearance of ${ }^{18} \mathrm{~F}-\mathrm{FDG}$ al (in presence of galactose; $K_{+ \text {gal }}^{*}$, $\mathrm{blood} / \mathrm{min} / \mathrm{L}$ liver tissue), are shown in C and D. All data shown in figure are from subject 3. demonstrated. The liver encompasses multiple functions, including metabolic, detoxifying, and excretory functions, and the present ${ }^{18} \mathrm{~F}-\mathrm{FDG}$ al PET/CT approach provides a method for measuring only one of these many functions. Therefore, it may be interesting to compare ${ }^{18} \mathrm{~F}$-FDGal PET with methods that evaluate other liver functions, such as ${ }^{99} \mathrm{Tc}-m e b r o f e n i n$ SPECT, which measures hepatic uptake and biliary excretion (1), or SPECT using ${ }^{99} \mathrm{Tc}$-labeled diethylenetriaminepentaacetic acid galactosyl human serum albumin, an asialoglycoprotein analog that binds to asialoglycoprotein receptors on the plasma-membrane of hepatocytes (2). Likewise, it may be interesting to compare the measurements of specific liver functions with measurements of metabolic pathways, including glucose metabolism measured by ${ }^{18}$ F-FDG PET (30) and fatty acid metabolism measured by ${ }^{11} \mathrm{C}$-palmitate PET (33) or regional changes in hepatic blood perfusion (34). Thus, it becomes possible to evaluate how different metabolic functions are affected in certain liver diseases and how different local treatments affect different metabolic liver functions.

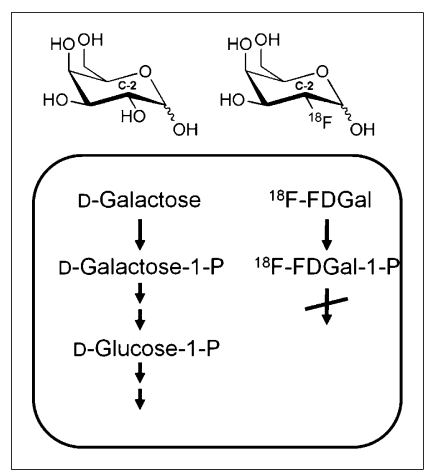

FIGURE 3. Molecular structures and hepatocellular metabolism of galactose and ${ }^{18} \mathrm{~F}-\mathrm{FDG}$ al. The hydroxyl group at carbon $2(\mathrm{C}-2)$ in galactose is replaced by ${ }^{18} \mathrm{~F}$ in ${ }^{18} \mathrm{~F}-\mathrm{FDGal}$, causing metabolism of ${ }^{18} \mathrm{~F}-$ FDGal to essentially stop after hepatocellular phosphorylation catalyzed by galactokinase.

\section{CONCLUSION}

The study shows that ${ }^{18} \mathrm{~F}-\mathrm{FDG}$ al is a substrate for human hepatic galactokinase and that dynamic ${ }^{18} \mathrm{~F}-\mathrm{FDGal} \mathrm{PET} / \mathrm{CT}$ provides an accurate measurement of hepatic galactose metabolism in vivo. The regional $\mathrm{V}_{\max }$ of galactose that was determined from PET/CT was $1.41 \pm 0.24 \mathrm{mmol} / \mathrm{min} / \mathrm{L}$ liver tissue, and this value was validated by direct, invasive measurements of the hepatic galactose kinetics. When the PET/CT study was performed without the galactose infusion, the hepatic systemic clearance of ${ }^{18} \mathrm{~F}-\mathrm{FDG} a \mathrm{l}$ was $0.274 \pm 0.001 \mathrm{~L}$ $\mathrm{blood} / \mathrm{min} / \mathrm{L}$ liver tissue and yielded an indirect measurement of the hepatic $\mathrm{V}_{\max }^{*}$ for ${ }^{18} \mathrm{~F}-\mathrm{FDG}$. The ${ }^{18} \mathrm{~F}-\mathrm{FDG}$ al PET/CT method enabled studies of the regional variations in hepatic galactokinase activity, which has hitherto not been possible, and the method is likely to prove clinically important for the prediction of remnant liver function in patients undergoing local treatment for liver diseases.

\section{DISCLOSURE STATEMENT}

The costs of publication of this article were defrayed in part by the payment of page charges. Therefore, and solely to indicate this fact, this article is hereby marked "advertisement" in accordance with 18 USC section 1734.

\section{ACKNOWLEDGMENTS}

This study was supported in part by the NIH (R01DK074419), the Danish Council for Independent Research (Medical Sciences, 09-067618 and 09-073658), the A.P. Møller Foundation for the Advancement of Medical Science, the Novo Nordisk Foundation, Aase and Ejnar Danielsen's Foundation, Christian and Ottilia Brorson's Foundation, and 
Helga and Peter Korning's Foundation. No other potential conflict of interest relevant to this article was reported.

\section{REFERENCES}

1. de Graaf W, van Lienden KP, Dinant S, et al. Assessment of future remnant liver function using hepatobiliary scintigraphy in patients undergoing major liver resection. J Gastrointest Surg. 2010;14:369-378.

2. Miki K, Kubota K, Inoue Y, Vera DR, Makuuchi M. Receptor measurements via Tc-GSA kinetic modeling are proportional to functional hepatocellular mass. J Nucl Med. 2001;42:733-737.

3. Sørensen M, Munk OL, Mortensen FV, et al. Hepatic uptake and metabolism of galactose can be quantified in vivo by $2-\left[{ }^{18} \mathrm{~F}\right]$ fluoro-2-deoxy-galactose positron emission tomography. Am J Physiol Gastrointest Liver Physiol. 2008;295:G27-G36.

4. Sørensen M. Determination of hepatic galactose elimination capacity using 2-[ ${ }^{18}$ F $]$ fluoro-2-deoxy-D-galactose PET/CT: reproducibility of the method and metabolic heterogeneity in a normal pig liver model. Scand J Gastroenterol. 2011;46:98-103.

5. Tygstrup N. Effect of sites of blood sampling in determination of the galactose elimination capacity. Scand J Clin Lab Invest. 1977;37:333-338.

6. Schmidt LE, Ott P, Tygstrup N. Galactose elimination capacity as a prognostic marker in patients with severe acetaminophen-induced hepatotoxicity: 10 years' experience. Clin Gastroenterol Hepatol. 2004;2:418-424.

7. Merkel C, Marchesini G, Fabbri A, et al. The course of galactose elimination capacity in patients with alcoholic cirrhosis: possible use as a surrogate marker for death. Hepatology. 1996;24:820-823.

8. Jepsen P, Vilstrup H, Ott P, Keiding S, Andersen PK, Tygstrup N. The galactose elimination capacity and mortality in 781 Danish patients with newly-diagnosed liver cirrhosis: a cohort study. BMC Gastroenterol. 2009;9:50.

9. Redaelli CA, Dufour JF, Wagner M, et al. Preoperative galactose elimination capacity predicts complications and survival after hepatic resection. Ann Surg. 2002;235:77-85.

10. Timson DJ, Reece RJ. Sugar recognition by human galactokinase. BMC Biochem. 2003;4:16.

11. Timson DJ, Reece RJ. Functional analysis of disease-causing mutations in human galactokinase. Eur J Biochem. 2003;270:1767-1774.

12. Skak C, Keiding S. Methodological problems in the use of indocyanine green to estimate hepatic blood flow and ICG clearance in man. Liver. 1987;7:155-162.

13. Frisch K, Bender D, Hansen SB, Keiding S, Sørensen M. Nucleophilic radiosynthesis of 2-[ $\left.{ }^{18} \mathrm{~F}\right]$ fluoro-2-deoxy-D-galactose from Talose triflate and biodistribution in a porcine model. Nucl Med Biol. 2011;38:477-483.

14. Kurz G, Wallenfels K. D-Galactose, UV-test mit Galactose-dehydrogenase. In: Bergmeyer HU, ed. Methoden der Enzymatischen Analyse. Weinheim, Germany: Verlag Chemie; 1970:1241-1244.

15. Gjedde A. Calculation of cerebral glucose phosphorylation from brain uptake of glucose analogs in vivo: a re-examination. Brain Res. 1982;257:237-274.
16. Patlak CS, Blasberg RG, Fenstermacher JD. Graphical evaluation of blood-tobrain transfer constants from multiple-time uptake data. J Cereb Blood Flow Metab. 1983;3:1-7.

17. Winkler K, Bass L, Keiding S, Tygstrup N. The physiological basis for clearance measurements in hepatology. Scand J Gastroenterol. 1979;14:439-448.

18. Crone $\mathrm{C}$. The permeability of capillaries in various organs as determined by use of the "indicator diffusion" method. Acta Physiol Scand. 1963;58:292-305.

19. Winkler K, Bass L, Henriksen J, Larsen OA, Ring P, Tygstrup N. Heterogeneity of splanchnic vascular transit times in man. Clin Physiol. 1983;3:537-544.

20. Keiding S, Johansen S, Winkler K. Hepatic galactose elimination kinetics in the intact pig. Scand J Clin Lab Invest. 1982;42:253-259.

21. Bass L, Keiding S, Winkler K, Tygstrup N. Enzymatic elimination of substrates flowing through the intact liver. J Theor Biol. 1976;61:393-409.

22. Keiding S, Johansen S, Winkler K, Tønnesen K, Tygstrup N. Michaelis Menten kinetics of galactose elimination by the isolated perfused pig liver. Am J Physiol. 1976;230:1302-1313.

23. Seber GAF, Wild CJ. Non-Linear Regression. New York, NY: John Wiley \& Sons; 1989.

24. Keiding S. Galactose clearance measurements and liver blood flow. Gastroenterology. 1988;94:477-481.

25. Doi R, Inoue K, Kogire M, et al. Simultaneous measurements of hepatic arterial and portal venous flows by transit time ultrasonic volume flowmetry. Surg Gynecol Obstet. 1988;167:65-69.

26. Henderson JM, Hanna SS. Effective liver blood flow: determination by galactose clearance. Can J Surg. 1983;26:129-132.

27. Diem K, Lentner C, eds. Documenta Geigy Scientific Tables. Switzerland: J.R. Geigy S.A; 1970.

28. Thoden JB, Timson DJ, Reece RJ, Holden HM. Molecular structure of human galactokinase: implications for type II galactosemia. J Biol Chem. 2005;280: 9662-9670.

29. Dixon M, Webb EC. Enzymes. Suffolk, U.K.: Longman; 1979.

30. Iozzo P, Jarvisalo MJ, Kiss J, et al. Quantification of liver glucose metabolism by positron emission tomography: validation study in pigs. Gastroenterology. 2007; 132:531-542.

31. Maharaj B, Maharaj RJ, Leary WP, et al. Sampling variability and its influence on the diagnostic yield of percutaneous needle biopsy of the liver. Lancet. 1986; 1:523-525.

32. Janiec DJ, Jacobson ER, Freeth A, Spaulding L, Blaszyk H. Histologic variation of grade and stage of non-alcoholic fatty liver disease in liver biopsies. Obes Surg. 2005;15:497-501.

33. Iozzo P, Bucci M, Roivainen A, et al. Fatty acid metabolism in the liver, measured by positron emission tomography, is increased in obese individuals. Gastroenterology. 2010;139:846-856.

34. Winterdahl M, Munk OL, Sørensen M, Mortensen FV, Keiding S. Hepatic blood perfusion measured by 3-min dynamic ${ }^{18}$ F-FDG PET in pigs. J Nucl Med. 2011; 52:1119-1124. 